Article

\title{
Conservation Payments, Off-Farm Labor, and Ethnic Minorities: Participation and Impact of the Grain for Green Program in China
}

\author{
Lunyu Xie ${ }^{1}$, Bohan Zeng ${ }^{1}$, Li Jiang ${ }^{1, *}$ and Jintao $\mathrm{Xu}^{2}$ \\ 1 School of Economics, Renmin University of China, 59 Zhongguancun Street, Beijing 100872, China; \\ lunyuxie@ruc.edu.cn (L.X.); zengbh92@ruc.edu.cn (B.Z.) \\ 2 National School of Development, Peking University, 5 Yiheyuan Road, Beijing 100871, China; \\ xujt@pku.edu.cn \\ * Correspondence: li.jiang@ruc.edu.cn; Tel.: +86-010-6251-1058
}

Received: 25 January 2018; Accepted: 3 April 2018; Published: 14 April 2018

\begin{abstract}
The Grain for Green program in China, a nationwide cropland set-aside program aimed at soil erosion prevention and poverty alleviation, was begun in 1999 and quickly expanded to 25 provinces, covering 32 million households. Its effects on participating households are well studied, but the role of ethnic characteristics is less well investigated. Given the overlap of areas covered by Grain for Green and areas inhabited by ethnic minorities, where development is a long-unresolved problem, it is important to determine how ethnic minorities react to, and benefit from, the Grain for Green program. This study investigates participation in the program by ethnic minorities and estimates its impact on their off-farm labor supply, compared with that of the ethnic majority, Han. We find that ethnic minorities were more likely to participate in the program, but enrolled similar area of land per household. However, ethnic minorities did not increase off-farm labor supply after participation in Grain for Green, while Han participants increased their off-farm labor supply significantly. These findings raise concerns that Grain for Green may have widened the income gap between Han and ethnic minorities. This study also provides important policy implications on sustainable land management for less-developed regions.
\end{abstract}

Keywords: Grain for Green; off-farm labor; ethnic minorities; difference-in-difference method; land degradation; sustainable land management

\section{Introduction}

Sustainable land management measures are used worldwide to protect land from ecosystem degradation and biodiversity loss [1-4], which are largely resulted from human activities [5]. Development interventions have been used to help achieve the sustainability of land through development activities, such as conservation payments to redirect labor from activities that harm ecosystems [6]. The Grain for Green program in China, a nationwide cropland set-aside program is a typical example of development interventions.

In Grain for Green, farmers set aside certain types of land and grow trees or grass instead. As compensation, central government provides them with annual subsidies: in-kind grain, cash payments, and free seedlings. The aims of the program are to prevent soil erosion and reduce poverty in rural areas. To achieve this goal, the participation and sustainability, and the long-term effects of the program on household production behavior, are critical.

A number of studies have investigated the participation and sustainability of the Green for Grain program [7-12], and evaluated its effect on off-farm labor and villagers' income, consumption, and investment [9,13-17]. Those studies generally found that Grain for Green increased off-farm labor 
employment and the associated income, but they also found that the effects varied significantly across household characteristics, such as initial level of human and physical capital.

Ethnic characteristics could be an important factor shaping the effects of the Grain for Green program as well, because much of the area covered by the program is inhabited by both the ethnic majority (Han) and ethnic minorities. Differences in household production behaviors between Han and ethnic minorities could lead to differences in their participation in the program, and different effects of the program. However, the potential impact of ethnic characteristics has not been well studied in the literature to date. Therefore, the aim of this study is to examine participation in the Grain for Green program and its effect on off-farm labor supply, focusing on the factor of ethnic characteristics. This study contributes to our understanding on the impacts of important cropland management changes in areas at risk for soil erosion and land degradation. In addition, insights derived from this study could improve evaluation of the effectiveness of the Grain for Green program and assist in development of sustainable land management strategies for less developed regions.

The primary target areas for the Grain for Green program are the basins of the Yellow and Yangtze rivers. Over $60 \%$ of the regions covered by the program are in the northwest, northeast and southwest of China, where ethnic minorities are concentrated, as shown by Figure 1. Our study area, Gansu Province (the black areas in Figure 1) is within these areas covered by the program and where ethnic minorities are concentrated. Previous research has shown that, compared with Han, ethnic minorities are more likely to use extensive production methods with lower levels of science and technology [18]. These minorities also have stronger religious beliefs and are less open to outside society. They have a lower level of education and less interaction with other ethnic groups, and are therefore more isolated from external influences [19]. These characteristics of ethnic minorities may lead to different participation rates in the Grain for Green program and different effects of the program to those on Han. Given that many of the areas below the poverty line in China are inhabited by ethnic minorities [20], their participation behavior and reaction to the program are critical for the program to achieve the goal of poverty reduction.

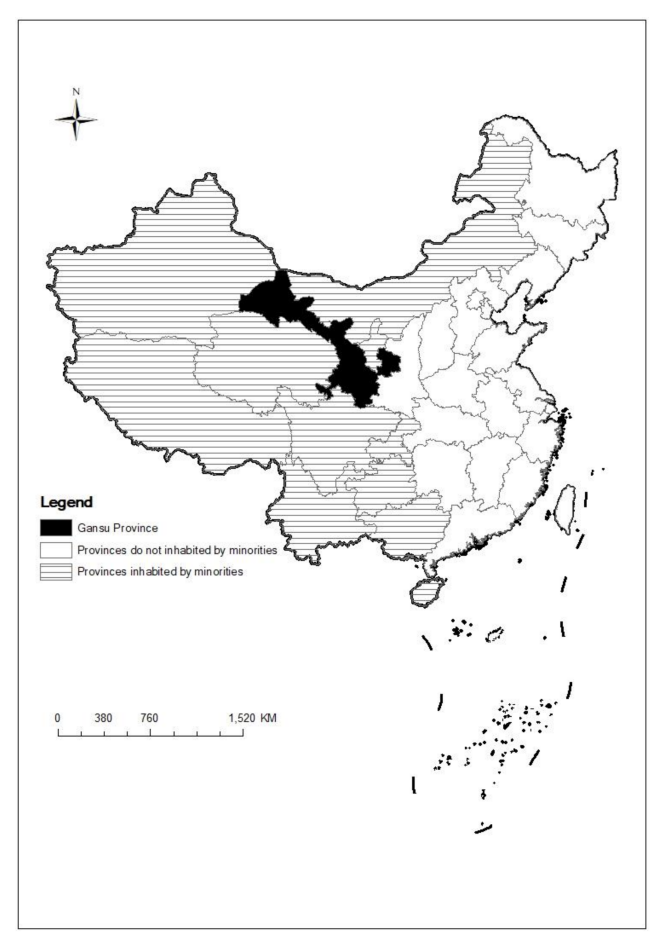

(a)

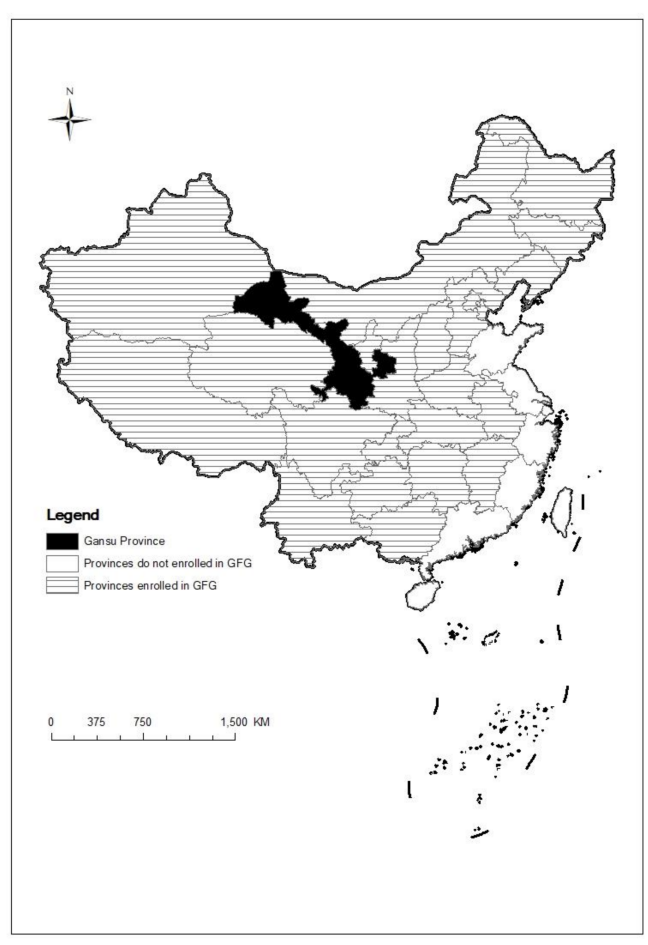

(b)

Figure 1. (a) Regions in China inhabited by ethnic minorities; (b) Regions covered by the Grain for Green program. 
By comparing Han and ethnic minorities living close by, we investigate whether being from an ethnic minority could help to explain differences in participation rates and the effect of the program on off-farm labor. We examine whether, all other conditions being equal, ethnic minorities participated equally in the program. We also examine how ethnic minority labor freed from land was used and whether education level played an important role in decisions on off-farm labor.

The remainder of this paper is structured as follows: Section 2 introduces the Grain for Green program and reviews related literature. Section 3 describes the survey and summarizes the data. Section 4 presents the identification strategy and the regression results. Section 5 concludes.

\section{The Grain for Green Program and Related Literature}

The Grain for Green program started with a pilot program in Sichuan, Shanxi, and Gansu provinces in 1999 and expanded quickly to 20 provinces by the end of 2001 [21], covering more than 2 million hectares [10]. When it was formally launched in 2003, the program covered 15 million farmers in more than 2000 counties in 25 provinces, municipalities, and autonomous regions [22]. By the end of 2013, the total area of afforestation under the program reached 29.8 million hectares [23]. The Grain for Green program involves conversion of steep-sloped and degraded cropland or barren land to forest or grassland by millions of farmers, who are compensated by grain and cash subsidies provided by central government. The annual grain subsidy is $100 \mathrm{~kg} / \mathrm{mu}$ in the Yellow River basin and $150 \mathrm{~kg} / \mathrm{mu}$ in the Yangtze river basin ( $1 \mathrm{mu}=0.0667$ hectare). Participating households also receive an annual cash subsidy of 50 Chinese Yuan per mu for managing and protecting the planted trees [24,25]. By 2013, the total subsidy paid by central government amounted to 354.2 billion Yuan and benefited a total of 32 million households [26]. The scale of the Grain for Green program in China makes it one of the world's largest conservation projects $[10,21]$.

According to the Sloping Land Conversion Program Plan (2001-2010), issued by the State Forestry Administration (SFA) in 2003, the official selection criteria for land qualifying for inclusion in Grain for Green include the slope, yield, distance to residence/road, soil quality, and the ecological impact of the land [27]. Qualifying plots are expected to have steeper slope, lower yield, and greater distance to residence/road, and surveys show it is true on average in practice [10,17]. Based on these criteria, the SFA and provincial and subprovincial forestry bureaus targeted general areas of land for enrollment and set quotas for local governments [28]. When a community is chosen and allocated to the quota, households in principle are allowed to decide to set aside all or part of the cultivated land and plant it with tree seedlings. However, in practice some households were "strongly encouraged" to participate [14]. Xu et al. (2006) [21] found that half of the participating households in the sample did not think they have the autonomy to decide whether or not to participate, and only $30 \%$ reported that they had the autonomy to choose the plots to retire. So this program is in practice quasi-voluntary [14].

A large number of previous studies have examined farmers' participation and reconversion choice in the Grain for Green program. Most of the studies found that there was crucial impact of opportunity cost of land on the participation decisions. Specifically, greater subsidies and higher income from off-farm employments increased the willingness to participate in the program $[7,10,11]$. In addition, Liu and Dong found that the way in which governments conveyed and implemented the policy had played an important role in the reconversion choice [8]. Chen et al. [11], and Wan and Li [7] found that household characteristics including age, education, household size, and land quality significantly affected farmers' participation decision in the program.

Participation in Grain for Green results in a decrease in the area of cropland, and therefore leads to reallocation of labor from farming or grazing to off-farm activities. Many previous studies have found that enrollment in the program has a significant positive effect on off-farm employment and associated income $[14,15,17]$. The mechanism includes labor substitution [17], relaxation of the liquidity constraint [14], and relaxation of the output constraint [16]. Previous studies have also found that the effect of the program on off-farm labor supply differs between households with different characteristics. For example, Uchida et al. found that individuals with limited education are less likely to shift to 
off-farm labor market after enrolling in the program [14]. Yao et al. found that households with better economic conditions and stronger political leadership transferred the off-farm labor at an accelerated speed [15]. Moreover, Groom et al. found that households facing institutional and market failures were unable to reallocate their labor toward the off-farm work that is attractively profitable [16].

Despite the large literature on investigating the factors affecting the participation decision and the effects of the program, no study has considered the factor of ethnic characteristics. The possible reasons could be that the samples in those studies covered only the majority Han, or that ethnic information was not collected in those studies. It is important to consider ethnicity when evaluating the effect of the program, because the ethnic minorities are concentrated in the target areas of the program. Given a lack of knowledge about their responses to the program, this program tends to be inefficient. In addition, the pervasive poverty issue existing in the minorities has been a long-lasting concern of the government $[18,20]$. Without treating the majority and the minorities as separate groups, this program may unexpectedly widen the gaps between them. Moreover, empirical evidence about ethnicity in China is quite limited. Most of these studies have sought to explain the differences in characteristics between the majority and the minorities (e.g., $[18,19])$, but the analysis is basically descriptive in nature. No study has systematically examined the differences in response to a policy or a factor between the majority and the minorities using econometric methods. Given the overlap of the areas covered by the program, the areas below the poverty line, and the areas inhabited by ethnic minorities, this paper aims to fill this important gap in the literature, by systematically investigating how the participation in the program and the effect of the program on off-farm labor employment vary between Han and ethnic minorities.

\section{Data}

The data analyzed in this study comprise survey data collected by the Environmental Economics Program in China (EEPC) at Peking University. The EEPC members surveyed 120 households in 12 villages in Gannan Tibetan Autonomous Region in Gansu province, collecting information in both 1997 and 2012. Equal numbers of villages on both sides of Qinling Ridge were randomly selected, as shown in Figure 2. Within each village, 10 households were randomly selected for interview in person. One household out of the 120 surveyed households has a serious data-missing problem, so we drop it from the data analysis. The sample for data analysis is 119 households in total. Information collected in interviews included: (1) individual characteristics, including age, gender, ethnicity, education, whether on the labor market, type of labor, etc.; (2) characteristics of households, including number of household members, number of children, etc.; and (3) information on land, including total land area, area enrolled in Grain for Green, quality of land, distances of land from residence and road, etc. Information on land characteristics are collected for each plot held by the surveyed household. Since the sampled area is a Tibetan autonomous region, the minority Zang (Tibetan) and the majority Han dominate. Therefore, in our sample, most of the minority individuals are from the Zang minority. We have 67 Han households, and 52 minority households. The 52 minority households include 51 Zang households and one minority Tu household. In this paper, we include the Tu minority in the analysis, for being representative of the ethnicity distribution of this area. We reran the summary statistics and the main regressions using the sample excluding the Tu household, and found that the results remained stable.

Around 40 percent of the households in the sample are involved in the Grain for Green program. On average, each household has about 0.21 hectares of land enrolled in the program, which accounts for six percent of the land they own. By assessing the participants' ethnicity and residence attributes, we find that most Han in the sample lived to the north of Qinling Ridge, and a large share of them did not participate in the program (Table 1). In contrast, the ethnic minorities lived to the south of Qinling Ridge, and a great share of them participated in the program. 

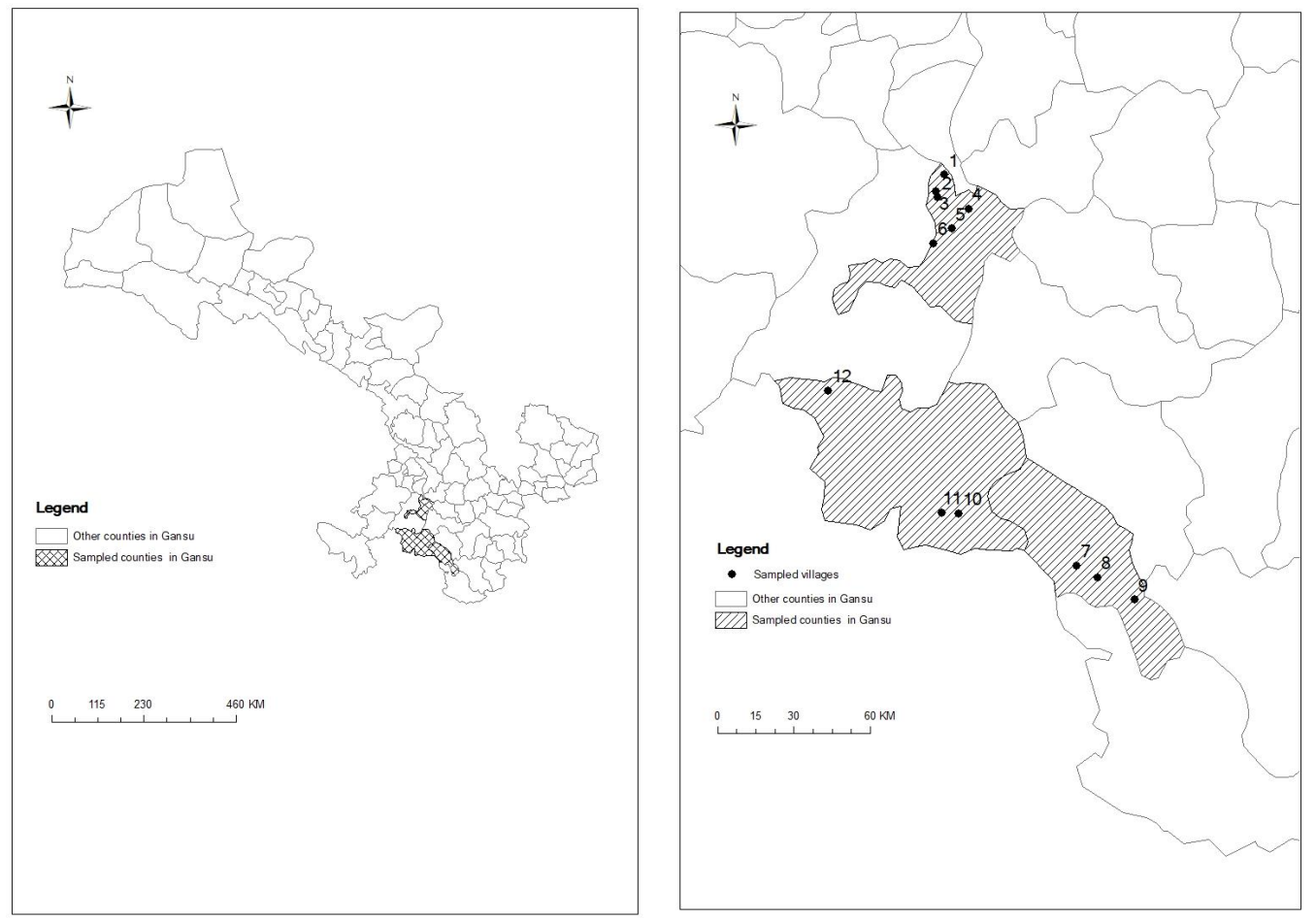

Figure 2. Spatial Distribution of Sampled Villages.

Table 1. The distribution of ethnic minorities and participants of the program in the sample.

\begin{tabular}{|c|c|c|c|c|c|c|}
\hline County Name & ID on Figure 2 & Village Name & Ethnic Minority & Han & Non-Participants & Participants \\
\hline \multirow{6}{*}{ Lintan } & 1 & Zhulin & 1 & 9 & 6 & 4 \\
\hline & 2 & Houshan & 0 & 10 & 8 & 2 \\
\hline & 3 & Hongjia & 1 & 9 & 10 & 0 \\
\hline & 4 & Qiuyu & 0 & 10 & 10 & 0 \\
\hline & 5 & Xinzhuang & 0 & 10 & 10 & 0 \\
\hline & 6 & Dacaotan & 0 & 9 & 9 & 0 \\
\hline \multirow{3}{*}{ Zhouqu } & 7 & Bazi & 0 & 10 & 2 & 8 \\
\hline & 8 & Jiaorao & 10 & 0 & 1 & 9 \\
\hline & 9 & Kankan & 10 & 0 & 1 & 9 \\
\hline \multirow{3}{*}{ Diebu } & 10 & Kelang & 10 & 0 & 3 & 7 \\
\hline & 11 & Nagao & 10 & 0 & 7 & 3 \\
\hline & 12 & Donggui & 10 & 0 & 3 & 7 \\
\hline Total & & & 52 & 67 & 70 & 49 \\
\hline
\end{tabular}

To investigate how participation is affected by household characteristics (especially ethnic background) and land, we compare the characteristics of households and land before the program for those enrolled in the program and those not enrolled. Summary statistics of relevant variables are listed in Table 2. As shown in Panel A, households enrolled in the program and those not enrolled are similar in 1997 (before the program) in terms of land characteristics (area of land, quality of land, distance from land to residence/road), but differ in terms of some household characteristics. For example, 74 percent of heads of households enrolled in the program are from ethnic minorities, while only 23 percent of heads of households not enrolled are from ethnic minorities. Moreover, enrolled households are less likely to have a male household head, have more children, and household size is larger. All these factors, which may affect the likelihood of participation for a household, are highly correlated. Therefore, we employ formal econometric models in the next section to disentangle the effects of these factors. We are especially interested in examining how the minorities differ in the likelihood of 
participation and the size of enrolled land, from the majority households with similar household and land characteristics.

Table 2. Summary statistics.

\begin{tabular}{|c|c|c|c|c|c|}
\hline \multirow{2}{*}{ Panel A. } & \multicolumn{2}{|c|}{ Non-Enrolled (Obs $=70 \mathrm{hhs})$} & \multicolumn{2}{|c|}{ Enrolled (Obs $=49$ hhs) } & \multirow[t]{2}{*}{ Difference } \\
\hline & Mean & S.D. & Mean & S.D. & \\
\hline \multicolumn{6}{|l|}{ Before Grain for Green (1997) } \\
\hline Ethnic minority (minority $=1$ ) & 0.229 & 0.423 & 0.735 & 0.446 & $0.506^{* * *}$ \\
\hline Education of household head (years) & 4.414 & 2.878 & 5.071 & 3.758 & 0.657 \\
\hline Age of household head (years) & 29.6 & 10.329 & 31.959 & 10.553 & 2.359 \\
\hline Gender of household head $($ male $=1)$ & 0.986 & 0.120 & 0.900 & 0.306 & $-0.086^{* *}$ \\
\hline $\mathrm{CCP}$ member $($ member $=1)$ & 0.1 & 0.302 & 0.122 & 0.331 & 0.022 \\
\hline Number of children & 1.371 & 1.092 & 2.041 & 1.154 & $0.67^{* * *}$ \\
\hline Number of household members & 4.771 & 1.374 & 5.367 & 1.510 & $0.596^{* *}$ \\
\hline Land area (ha) & 2.902 & 6.184 & 3.509 & 4.408 & 0.607 \\
\hline Land quality & 3.899 & 1.304 & 3.788 & 1.097 & -0.111 \\
\hline Distance from land to residence $(\mathrm{km})$ & 1.243 & 0.884 & 2.070 & 4.198 & 0.827 \\
\hline Distance from land to road $(\mathrm{km})$ & 0.985 & 1.548 & 0.912 & 1.019 & -0.073 \\
\hline \multicolumn{6}{|l|}{ After Grain for Green (2012) } \\
\hline Ethnic minority (minority $=1$ ) & 0.229 & 0.423 & 0.735 & 0.446 & $0.506^{* * *}$ \\
\hline Education of household head (years) & 4.543 & 2.879 & 5.327 & 3.794 & 0.784 \\
\hline Age of household head (years) & 44.071 & 9.338 & 46.020 & 10.527 & 1.949 \\
\hline Gender of household head $($ male $=1)$ & 0.986 & 0.120 & 0.900 & 0.306 & $-0.086 * *$ \\
\hline $\mathrm{CCP}$ member $($ member $=1)$ & 0.143 & 0.352 & 0.327 & 0.474 & $0.184^{* *}$ \\
\hline Number of children & 1.143 & 1.081 & 1.347 & 1.332 & 0.204 \\
\hline Number of household members & 5.329 & 1.359 & 5.755 & 1.877 & 0.426 \\
\hline Land area (ha) & 5.138 & 12.661 & 6.282 & 9.223 & 1.144 \\
\hline Land quality & 3.899 & 1.304 & 3.788 & 1.097 & -0.111 \\
\hline Distance from land to residence $(\mathrm{km})$ & 1.243 & 0.884 & 2.070 & 4.198 & 0.827 \\
\hline Distance from land to road $(\mathrm{km})$ & 0.985 & 1.548 & 0.912 & 1.019 & -0.073 \\
\hline Total subsidy (Chinese Yuan) & 0 & 0 & 596.3 & 563.3 & $596.3 * * *$ \\
\hline Enrolled area (ha) & 0 & 0 & 0.205 & 0.179 & $0.205 * * *$ \\
\hline Panel B. & \multicolumn{2}{|c|}{ Non-Enrolled } & \multicolumn{2}{|c|}{ Enrolled } & Difference \\
\hline Off-farm labor employment & Mean & S.D. & Mean & S.D. & \\
\hline Before Grain for Green (1997) & 0.429 & 0.672 & 0.245 & 0.434 & -0.184 \\
\hline After Grain for Green (2012) & 1.343 & 1.075 & 1.286 & 0.957 & -0.057 \\
\hline Panel C. & \multicolumn{2}{|c|}{ Non-Enrolled } & \multicolumn{2}{|c|}{ Enrolled } & Difference \\
\hline $\begin{array}{c}\text { Low-skilled Off-farm labor } \\
\text { employment }\end{array}$ & Mean & S.D. & Mean & S.D. & \\
\hline Before Grain for Green (1997) & 0.386 & 0.644 & 0.163 & 0.373 & $-0.223 *$ \\
\hline After Grain for Green (2012) & 1.300 & 1.095 & 1.122 & 0.971 & -0.178 \\
\hline Panel D. & Non-Enrolled & Enrolled & Difference & & \\
\hline $\begin{array}{c}\text { Off-farm labor employment requiring } \\
\text { higher education }\end{array}$ & Mean & S.D. & Mean & S.D. & \\
\hline Before Grain for Green (1997) & 0.043 & 0.266 & 0.082 & 0.277 & 0.039 \\
\hline After Grain for Green (2012) & 0.043 & 0.266 & 0.163 & 0.426 & 0.120 ** \\
\hline
\end{tabular}

Notes: Observations are at household level. CCP member is a dummy variable, which equals 1 if the head of the household is a member of Chinese Communist Party. Land quality is measured by the weighted average scores of soil quality, irrigation condition, and gradient. A Mann-Whitney $U$ test is used to test whether the average differences between the enrolled and the non-enrolled households are statistically significant. Stars after the difference indicate the significance level: ${ }^{* * *} p<0.01,{ }^{* *} p<0.05,{ }^{*} p<0.1$.

To investigate the effect of the Grain for Green program on off-farm labor supply, we compare off-farm labor both before and after introduction of the program between households enrolled and households not enrolled. As shown in Panel B in Table 2, off-farm labor employment increased in both groups, but increased more in the enrolled households (from 0.245 to 1.286 persons per household) than in the non-enrolled households (from 0.429 to 1.343 persons per household). This suggests that participating in Grain for Green stimulates more off-farm work. To enhance the comparability of the treatment and the control groups, we employ a regression based difference-in-difference (DID) method 
in the next section to quantify the treatment effect of the program on off-farm labor employment, focusing on the heterogeneity in the effects on minorities and the majority Han.

Besides the effects on total off-farm labor, we are also interested in the effects of the program on different types of off-farm labor. In China, a large portion of the off-farm labor are low-skilled workers, such as construction workers, waitress in restaurants, and so on. Only a small portion of the off-farm labor obtained jobs that required higher education, such as teacher, government secretory, etc. As shown in Panel C and Panel D of Table 2, the low-skilled off-farm labor constitute a very large portion of the total off-farm labor employment. For example, the average off-farm labor employment per household is 1.343 in the non-enrolled group after the program, and the figure for the low-skilled labor is 1.300 , which is over $95 \%$ of the total off-farm labor employment. Given the off-farm labor composition, the program is more likely to divert farm labor to low-skilled off-farm jobs, than to the jobs requiring higher education. In the next section, we employ regression models to quantify the treatment effects of the program on the two types of off-farm labor.

\section{Estimation and Results}

\subsection{Likelihood of Participation in Grain for Green}

We employ econometric models to investigate factors affecting participation in Grain for Green. We distinguish between extensive and intensive margins of participation, where the extensive margin refers to whether the household is enrolled in the program, and the intensive margin refers to the area of land enrolled in the program conditional on enrollment. Many factors affect participation, including age, gender, education, household size, land area, and so on. As we focus on whether being an ethnic minority household affected participation, all other characteristics of households and land being equal, we included as explanatory variables ethnicity and all other observed characteristics of households and their land holdings. Village dummies are also included in the regressions in order to compare households in the same village.

For the extensive margin, we employ a probit model to address the problem of a dummy dependent variable, using the full sample of 119 households before the program (in 1997). For the intensive margin, we employ a multiple linear regression (MLR) estimated by ordinary least square (OLS), using the subsample of 49 participants before the program. Regression results are listed in Table 3.

The first two columns show the results of the extensive margin. Column (1) includes all factors affecting participation except for ethnic characteristics, while Column (2) includes ethnic characteristics. The regression results show that, ceteris paribus, the probability of ethnic minorities participating in Grain for Green is $69 \%$ higher than the probability of ethnic Han participating. Compared with Column (1), the coefficients of other variables change, which illustrates the possible estimation bias if the ethnic factor is ignored. For example, when the ethnic factor is omitted, the effect of the subsidy on participation is overestimated (0.0069 and statistically significant in Column (1), compared with -0.0026 and not statistically significant in Column (2)).

Similarly, we estimate the intensive margin in Columns (3) and (4) without and with the variable of ethnic characteristics, respectively. The coefficient of ethnic minority is estimated to be negative, and not statistically significant. The coefficient is not economically significant either. Because compared with the average area of land for the treatment group before the program (2.902 ha), the estimated effect, $-0.0288 \mathrm{ha}$, is small. This indicates that enrolled ethnic minorities are similar to enrolled Han in terms of area of enrolled land. The possible explanation is that the program is quasi-voluntary [14]. There were program officers who were in charge of selecting participants and enrolled land, and they made decisions based on characteristics of each household's land holdings. Since minority is not explicitly targeted, it is not surprising to see similar land enrollment between the majority and the minorities with similar characteristics of land holdings. 
Based on the estimation results on the extensive and the intensive margins, we expect to find a positive total effect on the area of enrolled land. This is confirmed in Columns (5) and (6), the results from a tobit model using the full sample of 119 households. Tobit model is chosen to take account of the truncation issue that the area of enrolled land for non-participants is zero. The results show that the minorities enrolled 0.2776 ha more cultivated land in the program, compared to the majority with the same characteristics in the same village.

Besides ethnic characteristics, other factors are also found to affect participation likelihood or enrolled land area. They include number of children in the household and subsidy level. The estimation results are as expected: Households with more children have a higher incentive to participate in the Grain for Green program, as it can free labor from plowing and the household can hence put more labor into taking care of children. Households with a higher level of subsidy also have a higher incentive to enroll in the program. These are both household characteristics. In contrast, the characteristics of the household head (such as education, age) do not seem to have much impact on the participation decision, except for the ethnicity.

In sum, the difference in the participation between the minorities and the majority is a total effect of the differences in the observed characteristics between the two groups, as well as the differences in the unobserved characteristics captured in the ethnic minority dummy. Table 4 displays the characteristics of households, the differences in participation between the two groups, and the contribution of each characteristic to the difference in participation. It shows that about $70.6 \%$ of the ethnic minorities and $19.4 \%$ of the ethnic majority are enrolled in the program, and that the difference is mainly driven by the difference in ethnicity. Ethnic minority alone contributes 68.68 percentage points to the difference in participation, which means that a minority household is $68.68 \%$ more likely to participate in the program, compared to a majority household with all other household and land characteristics the same. Compared to ethnicity, the contribution of other characteristics is much smaller.

\subsection{Effect on Off-Farm Labor of the Grain for Green Program}

We investigate the effect of Grain for Green on off-farm labor supply using a difference-in-difference method (DID). A DID estimator is generally obtained as:

$$
\hat{\alpha}_{1}=\left(\bar{Y}_{11}-\bar{Y}_{10}\right)-\left(\bar{Y}_{01}-\bar{Y}_{00}\right)
$$

where $\bar{Y}_{\text {st }}=\frac{1}{N} \sum_{i} Y_{i s t}$ and $Y_{i s t}$ is the off-farm labor employment of household $i$ in group $s$ in year $t$, where $t$ equals 1 for the year after Grain for Green becomes effective and 0 for the year before, and $\mathrm{s}$ equals 1 for households taking part in the program, referred to as the treatment group, and 0 for households not in the program, referred to as the control group. We estimate the treatment effect of the program, $\hat{\alpha}_{1}$, in the following regression:

$$
Y_{i s t}=\alpha_{0}+\alpha_{1} D_{s t}+\alpha_{2} D_{s}+\alpha_{3} D_{t}+X^{\prime} \boldsymbol{\beta}+\varepsilon_{i s t}
$$

where $D_{s}$ is the group dummy, which equals 1 if household $i$ is in the treatment group, and 0 if in the control group; $D_{t}$ is the year dummy, which equals 1 if the observation is in the year after the program is in effect, and 0 if before; and $D_{s t}$ is the treatment indicator, which is the interaction term of the group dummy and the year dummy. The coefficient of the treatment indicator is the treatment effect of the program on $Y . X$ includes the observable variables which affect the off-farm labor supply of a household, including household characteristics (e.g., household size, education, etc.) and land characteristics (e.g., land area, distance from land to residence/road, etc.). $\varepsilon_{i s t}$ is the residual term. 
Table 3. Effects of household and land characteristics on participation in the Grain for Green program.

\begin{tabular}{|c|c|c|c|c|c|c|}
\hline & \multicolumn{2}{|c|}{$\begin{array}{c}\text { Dependent Variable: Whether Enrolled in } \\
\text { the Program }\end{array}$} & \multicolumn{2}{|c|}{$\begin{array}{l}\text { Dependent Variable: Enrolled Land Area } \\
\text { Conditional on Enrollment }\end{array}$} & \multicolumn{2}{|c|}{ Dependent Variable: Enrolled Land Area } \\
\hline & $\begin{array}{l}(1) \\
\text { Probit }\end{array}$ & $\begin{array}{l}(2) \\
\text { Probit }\end{array}$ & $\begin{array}{l}\text { (3) } \\
\text { OLS }\end{array}$ & $\begin{array}{l}\text { (4) } \\
\text { OLS }\end{array}$ & $\begin{array}{l}(5) \\
\text { Tobit }\end{array}$ & $\begin{array}{l}\text { (6) } \\
\text { Tobit }\end{array}$ \\
\hline Ethnic minority & & $\begin{array}{c}0.6868^{* * *} \\
(0.1422)\end{array}$ & & $\begin{array}{l}-0.0288 \\
(0.1437)\end{array}$ & & $\begin{array}{c}0.2776^{* * *} \\
(0.1055)\end{array}$ \\
\hline Education of household head & $\begin{array}{c}0.0042 \\
(0.0154)\end{array}$ & $\begin{array}{c}0.0108 \\
(0.0172)\end{array}$ & $\begin{array}{c}0.0027 \\
(0.0068)\end{array}$ & $\begin{array}{l}0.0027 \\
(0.007)\end{array}$ & $\begin{array}{l}-0.003 \\
(0.0305)\end{array}$ & $\begin{array}{l}-0.0038 \\
(0.0309)\end{array}$ \\
\hline Age of household head & $\begin{array}{l}0.0050 \\
(0.0042)\end{array}$ & $\begin{array}{c}0.0071 \\
(0.0046)\end{array}$ & $\begin{array}{l}0.0018 \\
(0.0033)\end{array}$ & $\begin{array}{c}0.0017 \\
(0.0038)\end{array}$ & $\begin{array}{l}0.0417 \\
(0.0338)\end{array}$ & $\begin{array}{l}0.0416 \\
(0.0342)\end{array}$ \\
\hline Gender of household head & $\begin{array}{l}-0.5150 * * * \\
(0.1017)\end{array}$ & $\begin{array}{l}-0.2524 \\
(0.2148) \\
\end{array}$ & $\begin{array}{l}0.0744 \\
(0.1133)\end{array}$ & $\begin{array}{c}0.0763 \\
(0.1138) \\
\end{array}$ & $\begin{array}{l}0.0027 \\
(0.0028)\end{array}$ & $\begin{array}{c}0.0029 \\
(0.0029) \\
\end{array}$ \\
\hline $\mathrm{CCP}$ member & $\begin{array}{l}-0.0064 \\
(0.1239)\end{array}$ & $\begin{array}{l}-0.1625 \\
(0.1185)\end{array}$ & $\begin{array}{c}0.0311 \\
(0.0903)\end{array}$ & $\begin{array}{c}0.0318 \\
(0.0924)\end{array}$ & $\begin{array}{c}0.0038 \\
(0.0063)\end{array}$ & $\begin{array}{c}0.0049 \\
(0.0060)\end{array}$ \\
\hline Number of children & $\begin{array}{l}0.1275 \\
(0.0896)\end{array}$ & $\begin{array}{c}0.1576 \\
(0.1015)\end{array}$ & $\begin{array}{c}0.0245 \\
(0.0243)\end{array}$ & $\begin{array}{c}0.0249 \\
(0.0263)\end{array}$ & $\begin{array}{c}0.0039 \\
(0.0874)\end{array}$ & $\begin{array}{l}-0.0008 \\
(0.0897)\end{array}$ \\
\hline Number of household members & $\begin{array}{c}0.022 \\
(0.0454) \\
\end{array}$ & $\begin{array}{c}0.0095 \\
(0.0516) \\
\end{array}$ & $\begin{array}{l}-0.0199 \\
(0.0222) \\
\end{array}$ & $\begin{array}{l}-0.0201 \\
(0.0227) \\
\end{array}$ & $\begin{array}{l}-0.062 \\
(0.0658) \\
\end{array}$ & $\begin{array}{l}-0.0703 \\
(0.0675) \\
\end{array}$ \\
\hline Land area & $\begin{array}{l}-0.0001 \\
(0.0007)\end{array}$ & $\begin{array}{l}-0.0001 \\
(0.0007)\end{array}$ & $\begin{array}{c}0.0156 \\
(0.0171)\end{array}$ & $\begin{array}{c}0.0154 \\
(0.0183)\end{array}$ & $\begin{array}{c}0.0005 \\
(0.0004)\end{array}$ & $\begin{array}{c}0.0005 \\
(0.0004)\end{array}$ \\
\hline Land quality & $\begin{array}{c}0.0102 \\
(0.0541)\end{array}$ & $\begin{array}{c}0.0089 \\
(0.0710)\end{array}$ & $\begin{array}{c}0.0131 \\
(0.0155)\end{array}$ & $\begin{array}{c}0.0113 \\
(0.0233)\end{array}$ & $\begin{array}{c}0.0432 \\
(0.0277)\end{array}$ & $\begin{array}{c}0.052 \\
(0.0348)\end{array}$ \\
\hline Distance from land to residence & $\begin{array}{c}0.0347 \\
(0.0295) \\
\end{array}$ & $\begin{array}{c}0.0316 \\
(0.0297) \\
\end{array}$ & $\begin{array}{c}0.0004 \\
(0.0039) \\
\end{array}$ & $\begin{array}{c}0.0004 \\
(0.0038) \\
\end{array}$ & $\begin{array}{c}0.0038^{* * *} \\
(0.0007)\end{array}$ & $\begin{array}{c}0.0004 \\
(0.0008) \\
\end{array}$ \\
\hline Distance from land to road & $\begin{array}{l}-0.0458 \\
(0.0383)\end{array}$ & $\begin{array}{l}-0.0489 \\
(0.0382)\end{array}$ & $\begin{array}{l}-0.0154 \\
(0.0269)\end{array}$ & $\begin{array}{l}-0.0158 \\
(0.0261)\end{array}$ & $\begin{array}{c}0.0015 \\
(0.0044)\end{array}$ & $\begin{array}{c}0.0009 \\
(0.0043)\end{array}$ \\
\hline Subsidy & $\begin{array}{c}0.0069^{* * *} \\
(0.0023)\end{array}$ & $\begin{array}{l}-0.0026 \\
(0.0028)\end{array}$ & $\begin{array}{c}0.0033 \\
(0.0021)\end{array}$ & $\begin{array}{c}0.0036^{* *} \\
(0.0012)\end{array}$ & $\begin{array}{l}-0.0147 \\
(0.0210)\end{array}$ & $\begin{array}{l}-0.0131 \\
(0.0212)\end{array}$ \\
\hline Constant & & & $\begin{array}{c}-10.4498 \\
(6.9711)\end{array}$ & $\begin{array}{c}-10.4615 \\
(6.0204)\end{array}$ & $\begin{array}{c}-1.0093 * * \\
(0.3913)\end{array}$ & $\begin{array}{c}-0.5451^{* *} \\
(0.2495)\end{array}$ \\
\hline R-squared & 0.225 & 0.329 & 0.322 & 0.322 & 0.843 & 0.858 \\
\hline Observations & 119 & 119 & 49 & 49 & 119 & 119 \\
\hline
\end{tabular}

Notes: Village dummies are included in the regressions. Observations are the 119 surveyed households before the program (in 1997). Columns (1) and (2) show the extensive margin based on a probit model. The marginal effects (not the coefficients of the probit model) are reported. Columns (3) and (4) show the intensive margin based on an ordinary least square (OLS) estimation. Since the intensive margin refers to the area of enrolled land conditional on enrollment, only the participants are included in the regression. Therefore, the sample size in Columns (3) and (4) is 49, the number of participants. In brackets are standard errors clustered at village level. Significance levels: ${ }^{* * *} p<0.01{ }^{* * *} p<0.05,{ }^{* *} p<0.1$. 
Table 4. Differences in household and land characteristics and the contributions to the difference in participation.

\begin{tabular}{|c|c|c|c|c|c|c|}
\hline & & $\begin{array}{c}\text { Minority } \\
(\mathrm{Obs}=52 \mathrm{hhs})\end{array}$ & $\begin{array}{c}\text { Majority } \\
\text { (Obs = 67 hhs) }\end{array}$ & Difference & $\begin{array}{l}\text { Estimated } \\
\text { Coefficient }\end{array}$ & $\begin{array}{c}\text { Contribution to Outcome } \\
\text { Difference (Percentage Point) }\end{array}$ \\
\hline & & (1) & (2) & (3) & (4) & (5) \\
\hline \multirow{3}{*}{ Outcome } & Participation rate (percentage point) & 70.6 & 19.4 & $51.2 * * *$ & & \\
\hline & Enrolled land area (ha) & 0.175 & 0.289 & $-0.114^{* *}$ & & \\
\hline & Proportion of enrolled land (percent) & 19.1 & 17.9 & 1.2 & & \\
\hline \multirow{12}{*}{$\begin{array}{l}\text { Characteristics of } \\
\text { households and lands } \\
\text { in } 1997\end{array}$} & Ethnic minority & 1 & 0 & $1 * * *$ & $0.6868^{* * *}$ & 68.68 \\
\hline & Education of household head & 4.49 & 4.836 & -0.346 & 0.0108 & -0.37368 \\
\hline & Age of household head & 30.1 & 30.9 & -0.8 & 0.0071 & -0.568 \\
\hline & Gender of household head & 0.923 & 0.97 & -0.047 & -0.2524 & 1.18628 \\
\hline & CCP member & 0.135 & 0.09 & 0.045 & -0.1625 & -0.73125 \\
\hline & Number of children & 1.615 & 1.672 & -0.057 & $0.1576^{* *}$ & -0.89832 \\
\hline & Number of household members & 5.096 & 4.955 & 0.141 & 0.0095 & 0.13395 \\
\hline & Land area & 7.67 & 9.813 & -2.143 & -0.0001 & 0.02143 \\
\hline & Land quality & 3.622 & 4.033 & $-0.411 *$ & 0.0089 & -0.36579 \\
\hline & Distance from land to residence & 2.156 & 1.139 & $1.017^{* *}$ & 0.0316 & 3.21372 \\
\hline & Distance from land to road & 1.259 & 0.719 & $0.54^{* *}$ & -0.0489 & -2.6406 \\
\hline & Subsidy & 213.8 & 160 & $53.8^{* * *}$ & -0.0026 & -13.988 \\
\hline
\end{tabular}

Notes: Columns (1) to (3) compare the characteristics between the majority and the minorities. A Mann-Whitney U test is used to test whether the average differences between the majority and the minorities are statistically significant. Stars after the difference indicate the significance level: $* * * p<0.01, * * p<0.05, * p<0.1$. By combing the difference in each characteristic (Column 3) and the estimated coefficient of the characteristic variable (Column 4), we calculate the contribution of each observed characteristic to the difference in participation between the two groups, and list the results in Column 5. 
In order to interpret these estimates as unbiased measures of the Grain for Green program, some assumptions must hold. One key assumption is the conditional unconfoundedness, which requires the similarity in outcome trajectories of the treatment and the control groups absent of any treatment effect. This assumption is to ensure comparability of the treatment and the control groups. If the two groups are not comparable, for example, households who prefer off-farm work are more likely to participate the program and the factors behind the preference are not observable and therefore not controlled in the regression-based DID, the DID estimate in this paper would overestimate the effect of the program on off-farm labor supply. One way to assess the plausibility of the conditional unconfoundedness assumption is to compare the pre-treatment trajectories of the two groups. Given that we have only one period data before the treatment, we are not able to compare the pre-treatment trajectories. Therefore, we rely on the implementation of the program and previous literature to assess the plausibility of the assumption. As we have discussed in the previous section, the program is in practice quasi-voluntary [14]. The self-selection problem is therefore alleviated. In addition, the program officers who were in charge of selecting participants and enrolled land made decisions based on characteristics of each household's land holdings, which were all observable. The regression based DID employed in this paper include all these characteristics as control variables, and therefore enhance the plausibility of the assumption of conditional unconfoundedness. Furthermore, Uchida et al., 2009 [14] studied the effect of the same Grain for Green program in China and adopted both traditional DID and DID matching methods. They found that the results with and without matching were similar. It implies that the control and the treatment groups in this program are comparable. The other key assumption for the validity of DID method is the assumption of stable unit treatment values (SUTVA), which requires that the off-farm labor supply of one household is independent of the treatment status of other households. This assumption is plausible, because the households are independent in household production and cultivated land management. One household's decision on off-farm labor supply is not likely to be affected by other households' decisions of participation.

The regression results are listed in Table 5, where Columns (1) and (2) show the values with and without village fixed effects, respectively. Since we are especially interested in the heterogeneous effect of the program on Han and ethnic minorities, we add the interaction term of the treatment indicator and the ethnic dummy variable. The coefficient of the interaction term shows the difference in the treatment effect between Han and ethnic minorities. The results show that the effect of the program on Han and ethnic minorities differs (the difference is -0.5958 and -0.9002 without and with village fixed effects, respectively) and that the difference is statistically significant. The effect on Han is positive and statistically significant $(0.5642$ and 0.7817 without and with village fixed effects, respectively), while the effect of the program on ethnic minorities is negative and not statistically significant $(0.5642-0.6342=-0.07, p$-value $=0.7404$ and $0.7817-0.9299=-0.1482, p$-value $=0.5870)$. This indicates that Han have increased off-farm labor supply after participating in the program, while ethnic minorities have not.

In Table 5, Column (3) through Column (6) present treatment variables providing more detailed information on the treatment. In Columns (3) and (4), the treatment variable is the ratio of enrolled land to total land area owned by the household. In Columns (5) and (6), the treatment variable is the amount of subsidy a household received for participation. The two continuous treatment variables are not likely to bring self-selection problem, because, as discussed above, the program is quasi-voluntary and the selection criteria are observed and controlled in the regressions. In addition, the subsidy per unit of land is set by the government and exogenous to households. The results from the regression with the continuous treatment variables are consistent with those from the regression with the binary treatment variables (whether to participate) in Columns (1) and (2): after participating in the program, Han have increased off-farm labor supply, while ethnic minorities have not.

Besides the Grain for Green program, there are some other factors affecting the off-farm labor supply. In Table 5, the estimated coefficients of ethnic minority are negative and statistically significant in the 
regression without village fixed effects, while they are positive (not statistically significant) with village fixed effects. One possible explanation is that minorities living in isolated villages, not intermingled with Han, tend to provide less off-farm labor on average compared with Han. As shown by our sample, the average off-farm labor per household is 0.62 for the minorities in a village where there is no majority resident, while the figure is 1.04 for the majority, and the difference is statistically significant. Without village dummies, this difference is captured by the coefficient of ethnic minority. Therefore, the estimated coefficient is negative. The reason behind the difference in off-farm labor employment could be that ethnic minorities are relatively isolated in society, and therefore may have less off-farm job opportunities, or they are less willing to participate in the off-farm labor employment [19]. However, when including village dummies, the comparison is between the households from the same village. Our sample shows that ethnic minorities living intermingled with Han have similar off-farm labor employment with Han households in the same village. Therefore, the coefficient of ethnic minority is expected to be not statistically significant when village dummies are included.

In addition, estimated coefficients of education of the household head are positive and statistically significant in all columns; estimated coefficients of land area are all negative and significant; and coefficients of distance from land to residence/road are also negative and significant in all columns. These results indicate that, ceteris paribus, households with a better educated head provide more off-farm labor on average, as higher education provides more off-farm job opportunities; households with more land and land farther away from residence/road provide less off-farm labor on average, as such households require more on-farm labor.

To distinguish between the treatment effects on different types of off-farm labor, we employ the same regression based DID on low-skilled off-farm labor employment and off-farm labor employment that requires higher education separately. The regression results are presented in Table 6 . It shows that the estimated treatment effect on low-skilled labor is at the same scale with that on total off-farm labor shown in Table 5, while the treatment effect on the higher-education labor is much smaller and not statistically significant. It implies that labor forces freed from the program are more likely to obtain a low-skilled off-farm job than a job that requires higher education. 
Table 5. Effects of the Grain for Green program on off-farm labor supply.

\begin{tabular}{|c|c|c|c|c|c|c|}
\hline & \multicolumn{6}{|c|}{ Dependent Variable: Number of Off-Farm Labor Units } \\
\hline & (1) & (2) 1 & (3) & (4) & (5) & (6) \\
\hline & OLS & $\begin{array}{c}\text { OLS with Village } \\
\text { FEs }\end{array}$ & OLS & $\begin{array}{c}\text { OLS with Village } \\
\text { FEs }\end{array}$ & OLS & $\begin{array}{c}\text { OLS with Village } \\
\text { FEs }\end{array}$ \\
\hline Minority $\times$ Treatment $\times$ Year & $\begin{array}{c}-0.6342 * * \\
(0.3157)\end{array}$ & $\begin{array}{c}-0.9299 * * \\
(0.3111)\end{array}$ & & & & \\
\hline Minority $\times$ Ratio $\times$ Year & & & $\begin{array}{l}-0.7087 \\
(1.4583)\end{array}$ & $\begin{array}{l}-1.9665 \\
(1.3328)\end{array}$ & & \\
\hline Minority $\times$ Subsidy $\times$ Year & & & & & $\begin{array}{l}-0.0005 \\
(0.0003) \\
\end{array}$ & $\begin{array}{c}-0.0009 * \\
(0.0004)\end{array}$ \\
\hline Treatment $\times$ Year & $\begin{array}{l}0.5642 * \\
(0.3079) \\
\end{array}$ & $\begin{array}{c}0.7817^{* *} \\
(0.2785) \\
\end{array}$ & & & & \\
\hline Ratio $\times$ Year & & & $\begin{array}{l}1.1483 \\
(1.332)\end{array}$ & $\begin{array}{l}2.1853 \\
(1.2204)\end{array}$ & & \\
\hline Subsidy $\times$ Year & & & & & $\begin{array}{l}0.0006^{*} \\
(0.0003)\end{array}$ & $\begin{array}{c}0.0009 * * \\
(0.0004)\end{array}$ \\
\hline Ethnic minority & $\begin{array}{l}-0.1330 \\
(0.1508) \\
\end{array}$ & $\begin{array}{l}0.5873^{*} \\
(0.3029) \\
\end{array}$ & $\begin{array}{c}-0.2794^{* *} \\
(0.1277)\end{array}$ & $\begin{array}{c}0.5166 \\
(0.3029) \\
\end{array}$ & $\begin{array}{c}-0.2324^{* *} \\
(0.1172) \\
\end{array}$ & $\begin{array}{l}0.5450^{*} \\
(0.2991) \\
\end{array}$ \\
\hline Education of household head & $\begin{array}{c}0.0399 * * \\
(0.0168) \\
\end{array}$ & $\begin{array}{c}0.0476^{* *} \\
(0.0206) \\
\end{array}$ & $\begin{array}{c}0.0407^{* *} \\
(0.0169)\end{array}$ & $\begin{array}{c}0.0503^{* *} \\
(0.0207) \\
\end{array}$ & $\begin{array}{c}0.0399 * * \\
(0.0167) \\
\end{array}$ & $\begin{array}{c}0.0491 * * \\
(0.0202) \\
\end{array}$ \\
\hline Age of household head & $\begin{array}{c}0.0044 \\
(0.0055) \\
\end{array}$ & $\begin{array}{c}0.0052 \\
(0.0067) \\
\end{array}$ & $\begin{array}{c}0.0037 \\
(0.0053) \\
\end{array}$ & $\begin{array}{c}0.0054 \\
(0.0071) \\
\end{array}$ & $\begin{array}{c}0.0037 \\
(0.0054) \\
\end{array}$ & $\begin{array}{l}0.0056 \\
(0.007)\end{array}$ \\
\hline CCP member & $\begin{array}{c}0.0851 \\
(0.1652) \\
\end{array}$ & $\begin{array}{c}0.0646 \\
(0.1858) \\
\end{array}$ & $\begin{array}{c}0.0723 \\
(0.1638) \\
\end{array}$ & $\begin{array}{c}0.0234 \\
(0.1734) \\
\end{array}$ & $\begin{array}{c}0.0718 \\
(0.1682) \\
\end{array}$ & $\begin{array}{l}0.0331 \\
(0.185) \\
\end{array}$ \\
\hline Number of children & $\begin{array}{l}-0.0513 \\
(0.0566) \\
\end{array}$ & $\begin{array}{l}-0.0468 \\
(0.0522) \\
\end{array}$ & $\begin{array}{l}-0.0596 \\
(0.0577) \\
\end{array}$ & $\begin{array}{l}-0.0556 \\
(0.0533) \\
\end{array}$ & $\begin{array}{l}-0.0574 \\
(0.0575) \\
\end{array}$ & $\begin{array}{l}-0.0537 \\
(0.0539) \\
\end{array}$ \\
\hline Number of household members & $\begin{array}{c}0.0363 \\
(0.0458) \\
\end{array}$ & $\begin{array}{c}0.0177 \\
(0.0493) \\
\end{array}$ & $\begin{array}{c}0.0377 \\
(0.0455) \\
\end{array}$ & $\begin{array}{c}0.0235 \\
(0.0522) \\
\end{array}$ & $\begin{array}{c}0.039 \\
(0.0454) \\
\end{array}$ & $\begin{array}{c}0.0234 \\
(0.0506) \\
\end{array}$ \\
\hline Land area & $\begin{array}{c}-0.0120^{* * *} \\
(0.0045)\end{array}$ & $\begin{array}{l}-0.0093 \\
(0.0053)\end{array}$ & $\begin{array}{c}-0.0106^{* *} \\
(0.0046)\end{array}$ & $\begin{array}{l}-0.0076 \\
(0.0054)\end{array}$ & $\begin{array}{c}-0.01144^{* *} \\
(0.0045)\end{array}$ & $\begin{array}{l}-0.0088 \\
(0.0052)\end{array}$ \\
\hline Land quality & $\begin{array}{l}-0.0467 \\
(0.0509)\end{array}$ & $\begin{array}{l}-0.0967 \\
(0.0806)\end{array}$ & $\begin{array}{l}-0.055 \\
(0.0517)\end{array}$ & $\begin{array}{l}-0.0986 \\
(0.0814) \\
\end{array}$ & $\begin{array}{l}-0.0496 \\
(0.0518) \\
\end{array}$ & $\begin{array}{l}-0.0922 \\
(0.0798) \\
\end{array}$ \\
\hline Distance from land to residence & $\begin{array}{l}-0.0255^{* *} \\
(0.0110)\end{array}$ & $\begin{array}{l}-0.0289 \\
(0.0175)\end{array}$ & $\begin{array}{c}-0.0276^{* *} \\
(0.0117)\end{array}$ & $\begin{array}{l}-0.0306 \\
(0.0173)\end{array}$ & $\begin{array}{l}-0.0280^{* *} \\
(0.0114)\end{array}$ & $\begin{array}{l}-0.0305 \\
(0.0184)\end{array}$ \\
\hline
\end{tabular}


Table 5. Cont.

\begin{tabular}{|c|c|c|c|c|c|c|}
\hline & \multicolumn{6}{|c|}{ Dependent Variable: Number of Off-Farm Labor Units } \\
\hline & (1) & (2) & (3) & (4) & (5) & (6) \\
\hline & OLS & $\begin{array}{l}\text { OLS with Village } \\
\text { FEs }\end{array}$ & OLS & $\begin{array}{c}\text { OLS with Village } \\
\text { FEs }\end{array}$ & OLS & $\begin{array}{c}\text { OLS with Village } \\
\text { FEs }\end{array}$ \\
\hline Distance from land to road & $\begin{array}{l}-0.0397 \\
(0.0435)\end{array}$ & $\begin{array}{c}-0.0101 \\
(0.048)\end{array}$ & $\begin{array}{l}-0.0284 \\
(0.043)\end{array}$ & $\begin{array}{c}0.0014 \\
(0.0499)\end{array}$ & $\begin{array}{l}-0.0317 \\
(0.0428)\end{array}$ & $\begin{array}{l}-0.0042 \\
(0.0448)\end{array}$ \\
\hline Enrolled area & $\begin{array}{c}0.0346 \\
(0.3821)\end{array}$ & $\begin{array}{c}0.0597 \\
(0.3807)\end{array}$ & & & & \\
\hline Treatment group & $\begin{array}{l}-0.1289 \\
(0.1652)\end{array}$ & $\begin{array}{c}0.0149 \\
(0.2819)\end{array}$ & & & & \\
\hline Ratio & & & $\begin{array}{l}-0.0725 \\
(0.2828)\end{array}$ & $\begin{array}{l}0.2132 \\
(0.407)\end{array}$ & & \\
\hline Subsidy & & & & & $\begin{array}{l}-0.0001 \\
(0.0001)\end{array}$ & $\begin{array}{c}0 \\
(0.0001)\end{array}$ \\
\hline Year dummy & $\begin{array}{c}0.8370^{* * *} \\
(0.1683)\end{array}$ & $\begin{array}{c}0.8299 * * * \\
(0.1443)\end{array}$ & $\begin{array}{c}0.8275^{* * *} \\
(0.1543)\end{array}$ & $\begin{array}{c}0.8207^{* * *} \\
(0.1315)\end{array}$ & $\begin{array}{c}0.8205^{* * *} \\
(0.1501)\end{array}$ & $\begin{array}{c}0.7933^{* * *} \\
(0.1316)\end{array}$ \\
\hline Constant & $\begin{array}{c}0.3298 \\
(0.3667)\end{array}$ & $\begin{array}{c}0.3472 \\
(0.6394)\end{array}$ & $\begin{array}{c}0.3985 \\
(0.3656)\end{array}$ & $\begin{array}{c}0.3708 \\
(0.6418)\end{array}$ & $\begin{array}{c}0.3692 \\
(0.3631)\end{array}$ & $\begin{array}{c}0.3654 \\
(0.6172)\end{array}$ \\
\hline Observations & 238 & 238 & 238 & 238 & 238 & 238 \\
\hline $\mathrm{R}-$ squared & 0.3479 & 0.4212 & 0.338 & 0.405 & 0.3426 & 0.4136 \\
\hline
\end{tabular}

Notes: Observations are at household level. Data are from 119 households observed before and after the program (1997 and 2012). The number of observations is therefore 238. Results in all columns are based on a difference-in-difference method. In columns (1) and (2) the treatment is measured by a dummy variable, which equals 1 if enrolled in the program, 0 otherwise. In columns (3) and (4) the treatment is measured by the ratio of enrolled land to the total land area. In columns (5) and (6) the treatment is measured by the total subsidies gain from the program. Columns (2), (4), and (6) include the village fixed effects (FEs), while columns (1), (3) and (5) do not. In brackets are standard error clustered at village level. Significance levels: $* * * p<0.01, * * p<0.05, * p<0.1$

Table 6. Effects of the Grain for Green program on low-skill and high-skill off-farm labor supply.

\begin{tabular}{|c|c|c|c|c|c|c|}
\hline \multirow{3}{*}{ Panel A } & \multicolumn{6}{|c|}{ Dependent Variable: Number of Low-Skilled Off-Farm Labor Units } \\
\hline & (1) & (2) & (3) & (4) & (5) & (6) \\
\hline & OLS & $\begin{array}{c}\text { OLS with Village } \\
\text { FEs }\end{array}$ & OLS & $\begin{array}{c}\text { OLS with Village } \\
\text { FEs }\end{array}$ & OLS & $\begin{array}{c}\text { OLS with Village } \\
\text { FEs }\end{array}$ \\
\hline Minority $\times$ Treatment $\times$ Year & $\begin{array}{l}-0.4217 \\
(0.3274)\end{array}$ & $\begin{array}{c}-0.7432 \\
(0.3805)\end{array}$ & & & & \\
\hline Minority $\times$ Ratio $\times$ Year & & & $\begin{array}{l}-0.9111 \\
(1.4487)\end{array}$ & $\begin{array}{c}-2.5453 * \\
(1.3560)\end{array}$ & & \\
\hline
\end{tabular}


Table 6. Cont.

\begin{tabular}{|c|c|c|c|c|c|c|}
\hline \multirow{3}{*}{ Panel A } & \multicolumn{6}{|c|}{ Dependent Variable: Number of Low-Skilled Off-Farm Labor Units } \\
\hline & (1) & (2) & (3) & (4) & (5) & (6) \\
\hline & OLS & $\begin{array}{l}\text { OLS with Village } \\
\text { FEs }\end{array}$ & OLS & $\begin{array}{l}\text { OLS with Village } \\
\text { FEs }\end{array}$ & OLS & $\begin{array}{c}\text { OLS with Village } \\
\text { FEs }\end{array}$ \\
\hline Minority $\times$ Subsidy $\times$ Year & & & & & $\begin{array}{l}-0.0005 \\
(0.0004)\end{array}$ & $\begin{array}{l}-0.0010^{* *} \\
(0.0004)\end{array}$ \\
\hline Treatment $\times$ Year & $\begin{array}{c}0.356 \\
(0.3236)\end{array}$ & $\begin{array}{c}0.5857 \\
(0.3283)\end{array}$ & & & & \\
\hline Ratio $\times$ Year & & & $\begin{array}{c}1.4866 \\
(1.3085)\end{array}$ & $\begin{array}{l}2.8170 * * \\
(1.2256)\end{array}$ & & \\
\hline Subsidy $\times$ Year & & & & & $\begin{array}{l}0.0006^{*} \\
(0.0003)\end{array}$ & $\begin{array}{l}0.0010^{* *} \\
(0.0004)\end{array}$ \\
\hline Observations & 238 & 238 & 238 & 238 & 238 & 238 \\
\hline R-squared & 0.3414 & 0.4059 & 0.3401 & 0.4049 & 0.3436 & 0.4132 \\
\hline \multirow{3}{*}{ Panel B } & \multicolumn{6}{|c|}{ Dependent Variable: Number of High-Skilled Off-Farm Labor Units } \\
\hline & (1) & (2) & (3) & (4) & (5) & (6) \\
\hline & OLS & $\begin{array}{l}\text { OLS with Village } \\
\text { FEs }\end{array}$ & OLS & $\begin{array}{l}\text { OLS with Village } \\
\text { FEs }\end{array}$ & OLS & $\begin{array}{c}\text { OLS with Village } \\
\text { FEs }\end{array}$ \\
\hline Minority $\times$ Treatment $\times$ Year & $\begin{array}{l}-0.2125 \\
(0.1840)\end{array}$ & $\begin{array}{l}-0.1867 \\
(0.1308)\end{array}$ & & & & \\
\hline Minority $\times$ Ratio $\times$ Year & & & $\begin{array}{c}0.2024 \\
(0.2511)\end{array}$ & $\begin{array}{c}0.5788 \\
(0.3727)\end{array}$ & & \\
\hline Minority $\times$ Subsidy $\times$ Year & & & & & $\begin{array}{l}-0.0000 \\
(0.0001)\end{array}$ & $\begin{array}{c}0.0001 \\
(0.0001)\end{array}$ \\
\hline Treatment $\times$ Year & $\begin{array}{c}0.2081 \\
(0.1847)\end{array}$ & $\begin{array}{l}0.1960^{*} \\
(0.1088)\end{array}$ & & & & \\
\hline Ratio $\times$ Year & & & $\begin{array}{l}-0.3383 \\
(0.2275)\end{array}$ & $\begin{array}{l}-0.6317^{*} \\
(0.3145)\end{array}$ & & \\
\hline Subsidy $\times$ Year & & & & & $\begin{array}{l}-0.0000 \\
(0.0001)\end{array}$ & $\begin{array}{l}-0.0001 \\
(0.0001)\end{array}$ \\
\hline Observations & 238 & 238 & 238 & 238 & 238 & 238 \\
\hline R-squared & 0.1193 & 0.196 & 0.1012 & 0.1872 & 0.0999 & 0.1843 \\
\hline
\end{tabular}

Notes: Observations are at household level. Results in all columns are based on the same difference-in-difference method as in Table 5, with the same explanatory variables included. Panel A estimates the treatment effect of the program on low-skilled off-farm labor employment. Panel B estimates the treatment effect on the off-farm labor employment that requires higher education. In columns (1) and (2), the treatment is measured by a dummy variable, which equals 1 if enrolled in the program, 0 otherwise. In columns (3) and (4), the treatment is measured by the ratio of enrolled land to the total land area. In columns (5) and (6), the treatment is measured by the total subsidies gain from the program. Columns (2), (4), and (6) include the village fixed effects (FEs), while columns (1), (3) and (5) do not. In brackets are standard error clustered at village level. Significance levels: ${ }^{* * *} p<0.01,{ }^{* *} p<0.05,{ }^{*} p<0.1$. 


\section{Conclusions and Discussion}

This study uses econometric models to examine the role of ethnic characteristics, along with other factors, in affecting participation in the Grain for Green program and off-farm labor. We find that, compared with Han, ethnic minorities are more likely to participate in Grain for Green, but the average land area enrolled per household is similar to Han, ceteris paribus. We also find that Han participants increase off-farm labor supply significantly after enrolling, while participating ethnic minorities show no significant increase in off-farm labor supply. In addition, we find that householders with better education are more likely to obtain off-farm labor work.

This study provides important policy implications on sustainable land management for less developed regions. The restoration and preservation of natural ecosystems is often a crucial and challenging issue in many less developed regions. Located in ecologically fragile areas, these regions are highly vulnerable to soil erosion and land degradation. Due to the lack of other means of livelihood, the long-term unsustainable way by which people crop their land has aggravated the problem. The goal of the Grain for Green program is to alleviate the tension between the preservation of natural ecosystems and the development of local inhabitants. Although this program provides conservation payment to farmers in exchange of setting aside cropland, it puts less attention to improving off-farm employment. Our results indicate that ethnic minorities have a relatively higher participation but a lower off-farm labor employment. Failing to obtain income increase from off-farm labor employment, ethnic minorities are likely to decrease their long-term willingness to participate in the program, and to more intensively crop their not-enrolled farmland. Both situations can lead to continuing ecological degradation.

Therefore, in order to achieve land use sustainability in less developed regions, integrated land management strategies which incorporate off-farm employment planning into the formulation of natural land preservation policy are critical. For example, the reason of a higher participation but a lower off-farm labor employment for ethnic minorities could be that ethnic minorities have a lower level of education. Therefore, improving educational infrastructure and providing vocational training for local inhabitants will be able to relax the constraint they face in off-farm employment opportunities. Moreover, development of service industry including ecological tourism or ethnic-featured tourism in less developed regions can create non-agricultural employment and absorb labor from farming. Once off-farm income becomes the primary income for local inhabitants, pressures on natural ecosystems will decrease.

The results also suggest that government should take the characteristics of local inhabitants into consideration when formulating and implementing sustainable land management policies. It is important to understand the heterogeneity in characteristics, respect the diversity of culture and convention, and foresee differences in reaction to a policy. In the present example, ethnic minorities and Han have unequal opportunities to share the achievements of a policy, showing less increase in off-farm labor supply, and therefore less increase in income. To help ethnic minorities benefit equally from policy, the government should readjust its development strategy for ethnic minority areas and formulate reasonable policies based on the specific situation in those areas, provide education infrastructure for ethnic minorities, and speed up plans to open up minority areas.

Acknowledgments: This research was supported by National Natural Science Foundation of China (Grant No. 71503252). Financial supports from Rights and Resources Initiatives (RRI) and the Environment for Development (EfD) Initiative at the University of Gothenburg, are gratefully acknowledged.

Author Contributions: Lunyu Xie conceptualized and designed the study, and wrote the paper. Bohan Zeng analyzed the data, and wrote the paper. Li Jiang jointly designed the study, and revised the paper. Jintao Xu jointly conceptualized the study, and provided the data. All authors read and approved the final manuscript.

Conflicts of Interest: The authors declare no conflict of interest. 


\section{References}

1. Cho, S.H.; Newman, D.H.; Bowker, J.M. Measuring rural homeowners' willingness to pay for land conservation easements. For. Policy Econ. 2005, 7, 757-770. [CrossRef]

2. Smith, R.B.W. The conservation reserve program as a least-cost land retirement mechanism. Am. J. Agric. Econ. 1995, 77, 93-105. [CrossRef]

3. Moon, K.; Cocklin, C. A landholder-based approach to the design of private-land conservation programs. Conserv. Biol. 2011, 25, 493-503. [CrossRef] [PubMed]

4. Shiferaw, B.; Holden, S.T. Resource degradation and adoption of land conservation technologies in the Ethiopian highlands: A case study in Andit Tid, North Shewa. Agric. Econ. 1998, 18, 233-247. [CrossRef]

5. Foley, J.A.; DeFries, R.; Asner, G.P.; Barford, C.; Bonan, G.; Carpenter, S.R.; Chapin, F.S.; Coe, M.T.; Daily, G.C.; Gibbs, H.K.; et al. Global consequences of land use. Science 2005, 309, 570-574. [CrossRef] [PubMed]

6. Ferraro, P.J.; Simpson, R.D. The cost-effectiveness of conservation payments. Land Econ. 2002, 78, 339-353. [CrossRef]

7. Wan, H.Y.; Li, C. Study on the participation in decision-making on sloping land conversion program for peasants. Stat. Res. 2013, 30, 83-91. (In Chinese)

8. Liu, Y.; Dong, Y. Factors' influencing farmers willingness to participate in Grain for Green project in the post-program era. Econ. Geogr. 2014, 34, 131-138. (In Chinese)

9. Yin, R.S.; Liu, C.; Zhao, M.J.; Yao, S.B.; Liu, H. The implementation and impacts of China's largest payment for ecosystem services program as revealed by longitudinal household data. Land Use Policy 2014, 40, 45-55. [CrossRef]

10. Uchida, E.; Xu, J.T.; Rozelle, S. Grain for Green: Cost-effectiveness and sustainability of China's conservation set-aside program. Land Econ. 2005, 81, 247-264. [CrossRef]

11. Chen, X.D.; Lupi, F.; He, G.M.; Ouyang, Z.Y.; Liu, J.G. Factors affecting land reconversion plans following a payment for ecosystem service program. Biol. Conserv. 2009, 142, 1740-1747. [CrossRef]

12. Guo, H.H.; Li, B.; Yu, H.Y.; Hao, L.X. Research on the Impact of “Grain for Green Project" on households' production and living conditions. China Popul. Resour. Environ. 2011, 21, 110-114. (In Chinese)

13. Uchida, E.; Xu, J.T.; Xu, Z.G.; Rozelle, S. Are the poor benefiting from China's land conservation program? Environ. Dev. Econ. 2007, 12, 593-620. [CrossRef]

14. Uchida, E.; Rozelle, S.; Xu, J.T. Conservation payments, liquidity constraints and off-farm labor: Impact of the Grain for Green Program on rural households in China. Am. J. Agric. Econ. 2009, 91, 70-86. [CrossRef]

15. Yao, S.B.; Guo, Y.J.; Huo, X.X. An empirical analysis of the effects of China's land conversion program on farmers' income growth and labor transfer. Environ. Manag. 2010, 45, 502-512. [CrossRef] [PubMed]

16. Groom, B.; Grosjean, P.; Kontoleon, A.; Swanson, T.; Zhang, S.Q. Relaxing rural constraints: A 'win-win' policy for poverty and environment in China. Oxf. Econ. Pap. 2010, 62, 132-156. [CrossRef]

17. Kelly, P.; Huo, X.X. Land retirement and nonfarm labor market participation: An analysis of China's sloping land conversion program. World Dev. 2013, 48, 156-169. [CrossRef]

18. Tong, Y.F.; Wang, H.X. The causes of poverty of ethnic population in Western-China and its policy implication. Popul. Econ. 2006, 154, 7-12. (In Chinese)

19. Ding, S. The ethnic minority-majority income gap in rural China. China Labor Econ. 2006, 3, 86-98. (In Chinese)

20. Xiang, L.L.; Deng, X.; Qu, X.S. Time-Spatial revolution of poverty in southwest ethnic minorities living area. J. Southwest Univ. Natl. 2013, 34, 124-129. (In Chinese)

21. Xu, Z.G.; Xu, J.T.; Deng, X.Z.; Huang, J.K.; Uchida, E.; Rozelle, S. Grain for green versus grain: Conflict between food security and conservation set-aside in China. World Dev. 2006, 34, 130-148. [CrossRef]

22. Xu, Z.G.; Bennett, M.T.; Tao, R.; Xu, J.T. China's sloping land conversion programme four years on: Current situation, pending issues. Int. For. Rev. 2004, 6, 317-326.

23. Wang, S.; Yue, X.M. The Grain-for-Green Project, non-farm employment, and the growth of farmer income. Econ. Res. J. 2017, 4, 009. (In Chinese)

24. State Forestry Administration (SFA). Master Plan for the Sloping Land Conversion Program; State Forestry Administration: Beijing, China, 2003.

25. State Council. Notice on the State Council's Improvement of the Farmland to Forests Policy; State Council: Beijing, China, 2007. 
26. State Forestry Administration (SFA). National Report on Ecological Benefit Monitoring of the Program of Grain-for-Green (2013); China Forestry Publishing House: Beijing, China, 2014.

27. State Forestry Administration (SFA). Sloping Land Conversion Program Plan (2001-2010); State Forestry Administration: Beijing, China, 2003.

28. Zuo, T. Implementation of the SLCP. In Implementing the Natural Forest Protection Program and the Sloping Land Conversion Program: Lessons and Policy Recommendations; Xu, J., Katsigris, E., White, T.A., Eds.; Forestry Publishing House: Beijing, China, 2002; pp. 33-49.

C 2018 by the authors. Licensee MDPI, Basel, Switzerland. This article is an open access article distributed under the terms and conditions of the Creative Commons Attribution (CC BY) license (http:/ / creativecommons.org/licenses/by/4.0/). 